\title{
Distant souls: post-communist emigration and voter turnout
}

\author{
Filip Kostelka ${ }^{1}$
}

Abstract: This article tackles the question of transnational electoral participation resulting from emigration. Drawing on several strands of political science literature, the theoretical section explains why emigration is likely to be detrimental to migrants' voting rates, which specific factors may affect these rates' variation and, overall, when and how emigration impacts nationwide voter turnout. The theory is then tested using original datasets on emigration, legal provisions for external voting and external voting rates in 10 Central and East European postcommunist democracies (CEE-10). The results confirm that external voting rates are much lower than domestic ones and reveal that their cross-national and over-time variation can be, to a large extent, explained by legal provisions for external voting and diaspora size. As a corollary of the weak transnational participation, emigration accounts for approximately one tenth of the fall in voter turnout that has occurred in the CEE-10 since the early 1990s.

Note: This is a manuscript accepted for publication in Journal of Ethnic and Migration Studies. It can be cited as follows:

Kostelka, Filip, 2017, “Distant souls: post-communist emigration and voter turnout", Journal of Ethnic and Migration Studies 43 (7), pp. 1061-1063

\footnotetext{
${ }^{1}$ Research Chair in Electoral Studies, Département de science politique, Université de Montréal, Montreal, Canada; Centre d'études européennes, Sciences Po, Paris, France. Contact : filip.kostelka@ sciencespo.fr
} 
One late evening in spring 2007, ten thousand Romanian citizens assembled in an amphitheatre to listen to the speech of the country's then president Traian Băsescu. An improvised stage was closely surrounded by the attendees who packed both the stands and the sandy central space. At stake was nothing less than Băsescu's presidential mandate. As a result of the domestic political struggle, he was facing an impeachment referendum triggered by Romania's Parliament. ${ }^{2}$ While he tried to galvanise the crowd, his supporters, refreshed by the spring breeze, were waving Romanian flags and holding banners expressing support for the president and his political party. Slogans in Romanian resonated in the surrounding streets... This could have been just a scene from one of the political rallies that were organized ahead of the 2007 referendum in large cities of Romania. Yet, this event was much less ordinary. The venue was neither Bucharest nor Cluj nor any other Romanian city. Băsescu met his fellow citizens in the bullring of the city of Castellon, Eastern Spain - more than 1500 kilometres away from the Romanian border and the remit of Băsescu's presidency. This paradoxical location in a Spanish sanctuary of corrida perfectly illustrates the gradually growing importance of a Europe-wide and, partly, transatlantic demographic dynamic. Attracted by better economic prospects and facing loosening obstacles, millions of post-communist citizens - substantial parts of some countries' electorates - moved abroad and, in particular, to the West.

This articles tackles transnational electoral participation resulting from emigration. The research question is twofold. First, to what extent do transnational voting rates ${ }^{3}$ differ from domestic ones and what accounts for their variation? Second, if they differ, what is the impact on nationwide turnout? I empirically study ten post-communist Central and European democracies (CEE-10) $)^{4}$ - most of whom experienced both strong emigration and a dramatic fall in electoral participation since the advent of regular, democratic elections in 1989 or soon thereafter. My analyses focus on the first six democratic contests in each country and combine original data on emigration rates, electoral legislation and external voting rates.

\footnotetext{
${ }^{2}$ The Romanian Parliament, controlled by a new majority after a series of political party splits, accused Traian Băsescu of unconstitutional behaviour (such as 'abuse of power' and 'infringement of the powers of the state institutions') and suspended him from office by 322 votes against 108 (and 10 abstentions) on $19^{\text {th }}$ April 2007. In conformity with the Romanian Constitution, this clearly politically motivated move triggered an impeachment referendum in which, however, $75 \%$ of voters supported Băsescu and refused the impeachment (cf. Gherghina and Miscoiu 2013: 674).

${ }^{3}$ In this article, I interchangeably employ the terms 'external voting' and 'transnational electoral participation' when referring to voting from abroad.

${ }^{4}$ Bulgaria, the Czech Republic, Estonia, Hungary, Latvia, Lithuania, Poland, Romania, Slovakia and Slovenia.
} 
With respect to the first research question, I confirm that transnational voting rates are expectedly much lower than the domestic ones. I break new ground by showing that legal provisions for external voting, of which registration procedures, and diaspora size can, to a large extent, explain variation in transnational voting rates. As for the second research question, I show that emigration contributes to the post-communist decline in voter turnout. According to my estimates, it accounts for approximately one tenth of the phenomenon. These findings demonstrate that international migration, the magnitude of which has been dramatically rising in the post-Cold War era (cf. Dumont and Lemaitre 2005), is an increasingly salient factor for understanding voter turnout variation over time and across countries.

I proceed as follows. I first formulate a number of general hypotheses on the relationship between emigration and voting based upon the existing literature on external voting and, in particular, on residential mobility. I expose why emigration should depress migrant's voting rates, which specific factors may affect these rates' variation and, overall, when and how emigration impacts nationwide voter turnout. To test these new theoretical claims, I subsequently focus more specifically on the CEE-10. In the second section, I present the data I use throughout the rest of the article. In the third section, I assess the extent and timing of postcommunist emigration. This allows me to estimate the number of post-communist citizens eligible to vote staying abroad during the period under study. In the fourth section, I describe the evolution of the provisions for external voting, which I expect, together with diaspora size, to account for cross-national variation in emigrants' voting rates. Finally, in the fifth section, I test the validity of my hypotheses through a regression analysis of external voting rates and I estimate the contribution of emigration to the post-communist voter turnout decline.

\section{Theoretical Considerations: Emigration and Voting}

In this section, I theoretically explain why emigrants' can be expected to vote less than their fellow countrymen back home and which factors may impact on the magnitude of the difference. I also discuss the likely implications for nationwide turnout. 
Emigration transforms voting in one's motherland from a national political activity into a transnational one. ${ }^{5}$ As emigrants' electoral participation extends across borders, it questions the classic linkage between citizenship and territorially-defined polity (Bauböck 2003). An important question for a student of political behaviour is whether and how the said transformation may affect the accomplishment of the voting act itself. Interestingly, this question has so far rarely been addressed in scientific literature. As several authors noted (Bauböck 2003, 708; Ostergaard-Nielsen 2003, 764; Lafleur and Chelius 2011, 100), the existing works have mostly focused either on immigrants' political engagement in the receiving country or on the impact of residential mobility (i.e. migration within a single polity). At the same time, the logic of residential mobility is, to some degree, similar to that of emigration. As a result, in developing my theory, I draw on the literature on residential mobility as well as the literature on external voting and the more general literature on who votes and why.

The impact of residential mobility on electoral participation has been notably studied in the United States, which has one of the highest moving rates in the developed world. All the existing studies on the United States concur that moving reduces one's propensity to vote (Verba and Nie 1972, 145; Wolfinger and Rosenstone 1980, 50-54; Squire, Wolfinger and Glass 1987; Rosenstone and Hansen 1993, 157; Highton 2000; Franklin 2005). Several distinct but related causal mechanisms explain this negative effect on propensity to vote. Using the classic cost-benefit conceptualisation of the voting act (Downs 1957), these mechanisms simultaneously increase the costs and reduce the benefits of the voting act.

The primary cause is voter registration, which is not automatic in most parts of the United States, unlike in Central and Eastern Europe and most other European countries. In the United States it must be accomplished as a separate administrative procedure, often well in advance of election day. When moving, U.S. citizens typically have to reregister in their new place of residence. If they fail to do so and want to cast a ballot, they have to return to their previous address to vote. For obvious reasons, this is costly (in terms of time, energy and, sometimes, money) and renders voting unlikely. This was empirically confirmed also in France, a European country where voter registration is not automatic like in the United States and where

\footnotetext{
${ }^{5}$ A transnational political activity may be defined as 'various forms of direct cross-border participation in the politics of their country of origin by both migrants and refugees [...] as well as their indirect participation via the political institutions of the host country' (Ostergaard-Nielsen 2003, 762).
} 
the 'malinscription' (registration at one's former address) was found to significantly hinder electoral participation (Braconnier et Dormagen 2007, chapter 2).

These arguments related to voter registration and malinscription are highly applicable to transnational electoral participation. To better explain this, we need to distinguish between two types of sending countries on the basis of their electoral legislation. The first type does not allow its citizens to vote externally in domestic elections. Emigrants from such countries find themselves de facto in an extreme situation of malinscription. If they wish to vote, they must return home, which implies an international journey and usually means they encounter more adverse conditions than within-country residential movers. In normal circumstances, very few voters would travel long distances and pay money for the mere sake of casting a vote in an election.

The second type of sending country allows for external voting in domestic elections. Emigrants from such countries can vote from the receiving country (i.e. their new domicile). But usually they still face a considerable constraint that substantially reduces their propensity to vote: registration. Most countries require their citizens to reregister when they want to vote from abroad (Green 2007, 98). Like in the case of within-country residential mobility or, actually, even more because of the geographical distance, this increases the costs of voting. The registration period often takes place before the election time where many citizens, not only abroad, are still unaware of the fact that an election will be held. They are thus particularly likely to be unaware of the registration procedure and deadlines.

As part of the pioneering empirical research on electoral behaviour, scholars have emphasised that voting is a social act (Lazarsfeld, Berelson and Gaudett 1948;-Campbellet al. 1960). People often participate in elections because they are told to do so and/or feel pressure to comply with the social norm of participation (Green and Shachar 2000). In other words, electoral participation is fostered by mobilisation, either by politicians and political activists ('direct mobilisation' according to Rosenstone and Hansen 1993, 25) or by one's peers ('indirect mobilisation'). The degree of either form of mobilisation is however substantially lower for mobile individuals. They are more difficult to reach by political campaigners and less socially connected, which reduces the social pressure that may compel them to vote 
(Rosenstone and Hansen 1993, 156-157). For example, in a work with a self-explanatory title ('You Want to Vote Where Everybody Knows Your Name'), Mark Franklin (2005) demonstrated that American young adults that moved out of their parents' neighbourhood are substantially less reactive to the electoral context (i.e. mobilisation) than their counterparts who stayed close to the family nest.

If within-country movers can easily escape being mobilised by activists or friends, this is particularly true for emigrants. In fact, direct mobilisation abroad varies in intensity depending on the likely impact of external votes on the election outcome. Since resources are scarce, campaigners have an interest in going transnational only when the diaspora is sufficiently large to affect the overall domestic result or when a certain share of electoral mandates is reserved for citizens abroad. Moreover, they can reach only emigrants well integrated in the diaspora's networks and/or living in countries/cities, where campaigning is cost-effective. These are, however, the same emigrants who are most likely to experience at least some indirect mobilisation, i.e. those who remain connected with their co-nationals. In contrast, emigrants who prefer integrating in the receiving country and/or avoid contacts with their co-nationals miss the mobilisation pressure altogether. Their decision to vote or abstain is entirely dependent on their attitudinal attributes, such as the perception of the voting act as a civic duty, interest in (domestic) politics, and perceived stakes and closeness of the election. However, and in contrast with within-country residential mobility, some of these attitudes are also likely to be negatively altered by emigration. In other words, besides increasing the costs, emigration is also likely to decrease the benefits of voting.

When citizens move from one region (or federalized state) to another in their motherland, this does not, ceteris paribus, alter the salience of the national election. The election campaign still makes the headlines in the media, and is discussed in workplaces, associations and local bars. In most cases, public policy resulting from the election (e.g. taxation), will affect all the constituent parts of the national territory equally. By contrast, emigrants are generally much less affected by public policy adopted in their country of origin (for example, they pay taxes abroad) and therefore typically feel less concerned about the election outcome. They also face substantial obstacles when accessing information on domestic politics in general, and the upcoming elections in particular. Those obstacles have lately greatly 
diminished thanks to modern technologies and social media. Yet, in comparison to their counterparts back home, emigrants are much less exposed to domestic political information and have to make more effort to access it. Their interest in the campaign and the election itself is thus strongly dependent on their degree of politicisation, which in turn hinges on their previous political socialisation and educational attainment. It is true that, under certain conditions such as high emigration costs or a wage-ratio favourable to highly skilled workers in the receiving countries (Chiswick 1999), emigrant's degree of politicisation can be expected to be relatively high because of emigrant's self-selection (i.e. their above-average social status). In such cases, the negative effect of lower stakes in domestic elections may be attenuated.

However, even if emigrants overcome all the preceding hurdles and remain motivated to vote, there is still one further step to make. Namely the voting act itself, which can be extraordinarily demanding. Before emigration, casting a ballot consists in a journey to the nearest polling station which, in most economically developed nations, is typically located walking distance from voters' domiciles. After emigration, unless external postal or online voting is provided, voting necessitates a visit to a diplomatic mission, a cultural institute or a similar institution where external polling stations tend to be opened. Such places are usually located in the receiving country's capital and, at best, some other large cities. For emigrants who are not fortunate to live in the neighbourhood of their country's representative institutions, the journey to the polling station is thus much more time-consuming. Moreover, if they live outside the capital (or one of the large cities in which it is also possible to cast a ballot), voting is also a financial burden. If emigrants decide to vote directly in their home country, which may enable them to jump the registration stage, the costs in terms of time and money become even greater.

Overall, there are many reasons why emigration depresses one's propensity to vote. On the empirical level, this theoretical expectation is largely corroborated by all the available evidence outside the CEE-10 (cf. Navarro, Morales and Gratschew 2007, 31).

At the same time, the extent to which emigrants' voting rates are lower than the domestic rates may, of course, vary. Drawing from the theoretical literature on voting behaviour, two factors can explain most of the variation. 
The first is the legislation concerning voter registration and the act of external voting itself. The nature of its effect is simple. As Lafleur and Chelious note $(2011,111)$, 'countries that have easy procedures to access external voting rights (such as Belgium or Italy) also have higher levels of participation.' In contrast, if external voting is burdensome and, in particular, if it requires prior reregistration ahead of the election, this is susceptible to reduce participation.

The other factor pertains to the size and location of the country's diaspora. All else being equal, we can expect higher participation by emigrants that are part of a larger and more geographically concentrated community of emigrants. The reason is that such a community is likely to attract a stronger and more efficient mobilisation effort by domestic parties (direct mobilisation), to be characterised by a more developed and dense network of emigrants' associations (indirect mobilisation) and, potentially, to be capable of putting pressure on the home-country authorities to adopt more liberal legislation on external voting (lower voting costs).

Nevertheless, despite its hypothetically positive effect on emigrants' turnout, diaspora size likely negatively affects the overall (i.e. nationwide) voter turnout rate. This is because, although voting rates of large communities of emigrants may be higher than those of smaller communities, they will, for all the reasons sketched above, never reach the domestic level. In other words, the more people emigrate, the higher emigrants' turnout (i.e. the share of emigrants who vote among all emigrants), but the lower the national turnout rate since a larger share of the total electorate has to vote from abroad where it is always costlier than back home.

These are the theoretical propositions that guide, inform and, at the same time, are tested in the ensuing, more empirical, sections of this article.

\section{Data}

This section reviews the sources and limitations of the data used throughout the article. The following empirical analyses require notably the calculation of external voting rates (i.e. the share of emigrants who vote in their country of origin). These rates correspond to the 
number of votes cast from abroad divided by the total number of CEE-10 emigrants that are eligible to vote in each election. I obtained the number of votes casts from abroad by courtesy of the national authorities of the ten countries at hand. As for the number of emigrants eligible to vote, I rely on mirror statistics from the host countries since reliable statistics from sending countries are unavailable. I focus on the principal destinations of CEE-10 migrants which are, as further discussed in Section 3 below, Western Europe, the United States and, a few other specific destinations for some of the CEE-10 citizens: Turkey (for Bulgarians), the Czech Republic (for Slovaks), Moldova (for Romanians). ${ }^{6}$ This focus is motivated by two reasons.

First, according to the available statistics compiled by the World Bank (Table 18 in the Electronic Appendix), the number of CEE-10-born residents in the rest of the world remained remarkably stable during the period under study. This means that the number of CEE-10 citizens living abroad increased in the first two post-communist decades exclusively because of emigration to the principal destinations. Therefore, when estimating the impact of emigration on the change in voter turnout, the reliance on the principal destinations does not induce a bias. ${ }^{7}$ The second reason is that for the principal destinations, yearly estimates of the number of residents from each CEE-10 are usually available and, therefore, the external voting rate can be calculated relatively accurately for each election.

The data come from official records such as censuses and population registers published by the national authorities in the host countries or research reports and databases that draw on such official records. These sources are presented in Table 1. Most of them present estimations

\footnotetext{
${ }^{6}$ In the case of Moldova, there has been no significant emigration from Romania. However, in the post-1989 period (and in particular after 2004), many Moldovans applied for Romanian citizenship, motivated by domestic political and economic conditions and, in particular, less stringent travel restrictions for Romanian citizens in Western Europe. Because of cultural and historical proximity, the Romanian authorities tended to answer favourably to these requests, which, however, were typically not followed by emigration to Romania (Knot 2014). Therefore, those Moldovans who benefited from this 'passportisation' became Romanian citizens abroad with voting rights (see Table 17 in the Electronic Appendix for detailed statistics).

${ }^{7}$ A bias may theoretically occur in the calculation of external rates due to an exclusion of those CEE-10 emigrants who emigrated before democratization. The potential for such a bias is however limited since pre-1989 emigrants were typically stripped of citizenship and voting rights after emigration by communist authorities (Dobreva 2013, 3). If some of pre-1989 emigrants reacquired the right to vote after 1989 while staying abroad, this actually renders the following estimates of the impact of emigration on voter turnout conservative. If the re-enfranchised pre-1989 emigrants were included, the external voting rates would be even weaker than this article portrays. Moreover, the exclusion of pre-1989 emigrants rules out the opposite bias, which would consist in including in the calculation of external voting rates those pre-1989 emigrants who would not be on the electoral rolls of their countries of origin.
} 
of emigrants' stocks by citizenship. ${ }^{8}$ To determine the number of those who are in the voting age, I use the available demographic statistics from the same sources, which estimate that $90 \%$ of CEE-10 emigrants are mobile adults in a productive age (see sources in Table 1: Holland et al. 2011, 52; U.S. Immigration and Naturalization Service 2002, 49).

[Table 1 about here]

The current data probably underestimate the degree of the CEE-10 emigration since official sources only imperfectly record migration flows that may take place without a direct contact between migrants and the receiving country's state authorities, such as free movement in the European Union or clandestine migration. Therefore, although all estimation of stocks is fraught with difficulty and the available data has its limits, the emigration figures used in this article are conservative and the effects of emigration described below may be, in reality, even more dramatic.

The other data used in empirical analyses pertain to population size, electorate size, and nationwide voter turnout rates, and legal provisions for external voting. The population data come from the World Bank statistics. ${ }^{9}$ Electorate size and voter turnout rates come from Nohlen and Stöver 2010, which was supplemented for the most recent elections with data available on the websites of the national electoral authorities. As for legal provisions for external voting, they were obtained from secondary sources and questionnaires sent to the CEE-10 national electoral authorities (see the note under Table 4 for details). The original data for all statistics cited in the following sections are available in the Electronic Appendix.

\section{Emigration from $\mathrm{CEE}^{10}$}

In this section, I estimate the total number of CEE-10 emigrants that were eligible to vote during the period under study. This number provides the denominator in the calculation

\footnotetext{
8 The principal exception is the United States statistics. It gives the yearly number of new permanent residents by country of birth. This means that, if some permanent residents decide to permanently leave the country during the period under study (which is not very likely given the difficulty of obtaining the status), the figure may slightly overestimate the stock. If it is the case, this his however attenuated by: a) the general tendency of the present data to underestimate the emigrations flows; b) the relatively weak contribution of the United States to the total emigration figure when compared with Western Europe.

9 World Bank, World Development Indicators, http://data.worldbank.org/data-catalog/world-developmentindicators, accessed October 27, 2014.

10 The present section provides just a brief summary of a more detailed survey of emigration from the CEE-10 that is available in Section 1 of the Electronic Appendix.
} 
emigrants' voting rates. The numerator is the number of votes cast from abroad, which is introduced in the final empirical section (Section 5).

From a historical perspective, East-West migration has been commonplace in modern Europe. Although the intensity and nature of the process has varied, Central and Eastern Europe has been a region of emigration since the industrial revolution, and Western Europe - followed by United States, Latin America and Australia - has been the main destination of CEE migrants (Kazczmarczyk and Okólski 2005; Goździak 2014, 1). Opportunities for such emigration were, however, severely curtailed by most communist regimes. Consequently, many western observers expected that the particular conjuncture of the fall of communism would lead to a surge in the East-West migrations flows. Their alarming predictions, spreading fears among Western publics, however proved unsubstantiated. In the first democratic decade, the number of CEE-10 citizens living in the principal emigration destinations increased solely by 0.8 million, reaching 1.8 in total (see Table 2). The ensuing developments (see below) suggest that the limited degree of post-communist emigration in the 1990s can be mainly attributed to scarce legal opportunities for employment in the West.

[Table 2 about here]

In fact, in the second democratic decade, the progressive dismantling of legal obstacles and, in particular, opening of labour in markets in Western Europe considerably reinvigorated the post-communist emigration flow. The increasingly favourable climate to labour migration, brought mainly by the CEE-10's accession to the European Union (in 2004 and 2007), multiplied the number of CEE immigrants living in the EU-15 (i.e. the fifteen pre-2004 member states) by five between 2000 and 2010. Altogether, by the end of the second post-communist decade, the number of CEE-10 citizens living in the principal emigration destination more than tripled and reached a striking 6.3 million (see Table 2), which corresponded to $6.3 \%$ of the total CEE-10 population (see Figure 1). To be sure, there was considerable variation within the region, which can be accounted for by several factors such as economic development or cultural proximity (Pytlikova 2006). The proportion of emigrants ranged from a modest $1.2 \%$ in the economically advanced Czech Republic to a striking $12.4 \%$ in less developed Romania. 
[Figure 1 about here]

As regards electorates, given the aforementioned over-representation of adults among emigrants (see Section 2), it can be estimated that $5.5 \%$ of the CEE-10 voters lived abroad by the sixth democratic election (see Table 3).

[Table 3 about here]

The expatriates' electoral strength did not pass unnoticed in the eyes of politicians back home. To the bewilderment of the locals, political advertising in narrowly-known foreign languages such as Polish and/or Romanian have become commonplace in a number of Western cities like London or Dublin since the mid-2000s. Domestic political meetings abroad, i.e. transnational political events like the one held in Castellon and described in the introduction of this article, are no longer unheard-of rarities. This mobilisation may have affected expatriates' voting rates. Nonetheless, as described in the first section of this article, external voting rates do not depend solely on diaspora size (and the related political mobilisation) but also on the legislation concerning the voting rights of non-residents and the provisions for external voting. These aspects are reviewed in the next section.

\section{Voting Rights of Emigrants and External Voting Provisions in CEE}

In order to understand the repercussions of strong emigration on voter turnout in the ten post-communist democracies, I show in this section that for each country we need to gather empirical data to answer four fundamental questions. First, do CEE emigrants keep their voting rights? Second, do they remain registered as eligible voters after having left their motherland? Third, is external voting provided for? Fourth, if it is possible to vote from abroad, how costly is it in terms of time, money and human energy? I now explore the answers to each question in turn.

As regards the first question, some liberal democracies such as Ireland condition the right to vote by permanent residency in the national territory. Others, notably Great Britain and former British colonies, specify the maximal period for which a citizen can stay abroad in order 
not to lose their right to vote (cf. Navarro, Morales \& Gratschew 2007, 11). In CEE-10, the only country to apply a limitation of this sort was Hungary. Throughout the first six democratic elections, the Hungarian authorities followed the Irish model and restricted the right to vote to citizens permanently residing in the country. ${ }^{11}$ Nevertheless, this restriction did not disenfranchise most Hungarian emigrants since they did not have a particular reason for reporting their emigration to the state authorities. Most kept their official permanent residence in Hungary - and thus their registration on the electoral rolls - although they were physically living elsewhere. This is obvious from a comparison of the official national Hungarian statistics on emigration and the mirror statistics on the number of Hungarian migrants provided by the receiving countries. The former figure, which de facto corresponds to the number of disenfranchised emigrants, is in some years up to 20 times lower than the latter figure, which gives the total number of emigrants (cf. Gödri, Soltész and Bodacz-Nagy 2014, 30). ${ }^{12}$

More generally, in all CEE-10, electoral rolls are kept on the basis of population registers. Voter registration is thereby automatic, which answers the second question raised above. Unless they lose citizenship or, until 2010 in the Hungarian case, officially declare permanent residence abroad, CEE citizens remain registered to vote from the time they reach the voting age of 18 years to grave. This has an important implication for voter turnout. The automatic nature of voter registration means that, excepting the pre-2010 official Hungarian emigrants, all post-communist emigrants who possess their home country's citizenship remain an integral part of their home country's electorate. In other words, when nationwide voter turnout rates are calculated, all adult citizens who stay abroad at the time of an election are included. This leads to the third question concerning the possibility of external voting.

At the international level, the adoption of external voting in nationwide elections has become the norm over the recent decades, which can be attributed notably to the third wave of democratisation and the growing international migration after the fall of the Iron Curtain (Nohlen and Grotz 2007, 65; Lafleur \& Chelius 2011, 102-103). As of May 2007, it was provided for in 115 countries and territories in the world, of which 41 were in Europe (cf.

\footnotetext{
${ }^{11}$ This limitation was lifted in May 2010 by the right-wing Fidesz that wished to enfranchise Hungarian ethnic minorities living in neighbouring countries.

${ }^{12}$ Given its negligible magnitude, the disenfranchisement of the fraction of Hungarian emigrants is not taken into account in the estimations made in this article.
} 
Navarro, Morales and Gratschew 2007, 11). Post-communist democracies have conformed to this general trend; most of them enacted provisions for external voting in the early 1990s. The only CEE-10 countries that did not offer their citizens an opportunity to vote from abroad shortly after democratisation were Hungary and the two successor states of the former Czechoslovakia. In Hungary, external voting did not exist under communism and, in view of the post-communist residency condition for the right to vote, it is not surprising that it was introduced late (before the legislative election of 2006). Until 2010, it benefited only those Hungarian citizens who were staying abroad, at least officially (see above), on temporary basis. The late adoption in the Czech Republic and Slovakia is more astonishing since external voting was practiced in pre-1989 Czechoslovak elections. For more than a decade, the two new democracies thus applied a narrower version of voting rights than the preceding communist dictatorship. Moreover, when the two countries eventually adopted the necessary legal provisions in 2000 (the Czech Republic) and 2004 (Slovakia), their character remained fairly restrictive, as the ensuing paragraphs demonstrate.

After the Hungarian, Czech and Slovak reforms, citizens of all CEE-10 could vote from abroad. Whether they were actually likely to do so largely depended on the concrete procedure of external voting. Its complexity has varied both over time and across the ten democracies. Although casting a vote remained vastly easier for domestic voters, external voting tended, in line with the aforesaid democratisation zeitgeist, to become simpler and more flexible. In step with the increasing emigration, the number of external polling stations has steadily risen - for instance, in Bulgaria, it increased from 157 in 2001 to 428 in 2014 (OSCE 2001, 2015). CEE emigrants were also progressively granted several options for taking part in national elections. The most common was voting in person at their country's foreign representations, such as embassies or consulates. But, often they could also cast their vote by post or, in the case of Estonia, even electronically. Registration for external voting has become less constrained too and, in Romania, Bulgaria and, in practice, Slovenia (cf. below), it was removed altogether.

\section{[Table 4 about here]}

This being said, the cross-national variation remains strong (see Table 4). In the seven remaining countries, registration is still required and, in cases such as the Czech Republic or 
Slovakia, it has to be accomplished more than one month ahead of the election day. The two successor states of former Czechoslovakia adopted the overall least voter-friendly legal provisions. As well as the early registration requirement, they allow for only one form of external voting (personal in the Czech case and, less demanding, postal in the Slovak case). In case of Romania, the absence of registration, favourable to emigrants' participation, has been at least partly dampened by logistical problems in the organisation of external voting. Since the second democratic decade, Romania's have expatriates regularly denounced the insufficient capacity of polling stations abroad, resulting in hours of waiting and sometimes even preventing them from casting a vote. Moreover, Romania has also disjointed legislative and presidential elections, which used to be held simultaneously until 2004 (Comşa 2015). Given the high costs of external voting, this reform is particularly likely to depress external turnout in the less important election type. In the Romanian case, this is, unlike in most other CEE-10, legislative elections. By contrast, Slovenia has clearly the most favourable institutional setup for expatriates' electoral participation. Not only are both postal and personal external voting allowed but, since a legislative reform of 2006, the Slovenian State Election Commission sends ballots to all Slovenian citizens who are residing abroad even if they do not demand it (OSCE 2012, 21). Expatriates are urged to report their new domicile and the addresses of all those citizens who have not declared a permanent address in Slovenia are searched for. When a Slovenian citizen visits a representation mission, for whatever reason, they are asked to communicate their current address (Trampuš 2007). The registration of Slovenians abroad thus becomes, de facto, automatic. What is more, the Slovenian Electoral Commission also acts as a mobilisation agent since, by sending election materials to all citizens abroad, it reminds them of the upcoming election. In 2008, it sent out approximately 40000 ballots (Bertelsmann Stiftung 2009, 7), which according to my estimates presented in Section 3, covers the bulk of Slovenia's expatriates.

The present section explored the conditions for transnational electoral participation in CEE. Its findings have two main implications. First, as voter registration has been automatic and, with the minor pre-2010 Hungarian exception, unrelated to residency status, the strong emigration is likely to have negatively impacted voter turnout in the region. Second, given the over-time and cross-country differences in the legal provision for external voting (and, of 
course, in the emigration rates), the impact of emigration was presumably unequal across countries and period. This is empirically tested in the next and final section of this article.

\section{Emigration, External Voting and Voter Turnout Dynamics in CEE}

As mentioned in the introduction, nationwide voter turnout severely slumped in the postcommunist region over the first two democratic decades. By 2012, when all of the CEE-10 had held at least six democratic elections, the average voter turnout rate decreased by 25.1 percentage points from $81.5 \%$ (in the founding democratic elections) to $56.4 \%$ (in the sixth election). Since the Second World War, no other democratic region has recorded such a dramatic fall of electoral participation (Kostelka 2015: Chapter 1). The conventional explanations of the phenomenon pertain to disenchantment with democratic politics and lower electoral stakes (cf. Kostadinova 2003; Pacek, Pop-Eleches and Tucker 2009, see Kostelka 2014 for a dicussion). With the important exception of a study by Comşa (2015), who finds that emigration contributes to the decline in Romania, this factor has not been taken into account by the existing studies on post-communist voter turnout dynamics. This final section addresses the emigration question by fulfilling two tasks. It first analyses variation in external voting rates in CEE elections, which also allows for testing the new theory from Section 1. Subsequently, it estimates the impact of emigration on the post-communist voter turnout decline.

\section{External Voting Rates}

Figure 2 shows the evolution of both the average nationwide voting rate and the average external voting rate in the first six democratic elections. Figure 3 breaks down these statistics by country. To calculate the external voting rates, the estimated number of CEE citizens in the voting age that live abroad (see Section 3 ) is entered in the denominator. In the numerator, there is the number of votes cast from abroad, which come from the official records of the national electoral authorities and which is presented in Table 9 in the Appendix.

[Figure 2 about here] 
It is evident that external voter turnout is much lower than domestic, in line with the theory outlined earlier in this article. In an average legislative election that provides for external voting, less than $20 \%$ of CEE citizens abroad cast a vote. In addition, this rate has been progressively declining, copying the trend in the nationwide turnout. This suggests that postcommunist emigrants were affected by similar factors as their fellow citizens living in the motherland. For instance, even when residing abroad, CEE citizens probably saw greater stakes in the first democratic elections than in the most recent ones. ${ }^{13}$

[Figure 3 about here]

Even though the external voting rates are much lower than domestic voting rates in all CEE-10, Figure 3 reveals that there is still a considerable cross-national and over-time variation in the magnitude of the rates. At the end of the period, they range from more than $32 \%$ in Slovenia's fifth election to a little more than $1 \%$ in Romania's sixth election. To explore this variation systematically, I ran five OLS regression analyses of the external voting rates from the second democratic decade. ${ }^{14}$

The principal independent variables are the factors advanced by the theory formulated in section 1, which are legal provisions for external voting, and diaspora size. Among legal provisions, I operationalise registration rules, which are the most constraining and burdensome element of external voting as they may double the effort necessary to cast a vote. ${ }^{15}$ The variable Registration measures how many days ahead of an election it is necessary to register before an election to be eligible to vote from abroad. If no registration is required, the variable is set to

\footnotetext{
${ }^{13}$ It should be noted that the statistics from the first democratic years may slightly exaggerate the initial electoral zeal of post-communist emigrants. As accurate estimates are unavailable, the total number of emigrants (i.e. the denominator in the calculation of external voter turnout) does not comprise those pre-1989 emigrants who, after their disenfranchisement by communist authorities (see Note 6), re-acquired the right to vote without resettling in their country of origin. Although their absolute numbers were generally low and declining in time because mortality brought about by ageing, their contribution to external voter turnout may have not been, in some cases, entirely negligible before the acceleration of post-communist emigration in the 2000s. Especially in Estonia and Latvia, the re-acquirement of citizenship was facilitated for pre-1989 emigrants to reduce the demographic weight of the two countries' Russian-speaking minorities, perceived as a threat to national independence.

${ }^{14}$ The analysis does not include the external rates from the first decade (the first four democratic elections) since they are less reliable (cf. Note 13), or unavailable as some countries adopted external voting only later on (Czech Republic, Hungary, Slovakia) or did not archive the data on external voting (Slovenia).

${ }^{15}$ Other attributes of external voting are not tested given the small number of observations.
} 
zero. As for diaspora size, the variable Electorate Abroad corresponds to the share of emigrants as a percentage of their country's electorate. The other confounding factors that impact voter turnout (for a general overview, see Blais 2006), are controlled via Domestic Turnout. ${ }^{16}$ The logic is straightforward: the higher the domestic voting rate, be it because of the election context (e.g. closeness of the election) or a long-term cultural traits favourable to participation (Voicu and Comşa 2014), the higher the external voting rate should be. The descriptive statistics for all these quantitative variables are presented in Table 5. In addition to the quantitative variables, all the regression models incorporate dummy variables for Slovenia and Romania because of the aforementioned exceptional activism of Slovenia's electoral commission, and the logistical problems and importance of the presidential election in Romania. Finally, to take into account the (short) panel structure of the data, the last two regression models apply panel-corrected standard errors and fixed effects (Beck 2001). ${ }^{17}$

[Table 5 about here]

The results, presented in Table 6, conform to the theoretical expectations formulated in section 1. All the regression coefficients are in the hypothesised direction and are statistically significant. According to Model 4, the fact of having to register for external voting decreases external voter turnout by about 0.11 percentage points for each extra day that separate the registration deadline from the actual election. Conversely, every increase in the number of voters abroad (as a percentage of the total electorate), boosts external voter turnout by 0.5 (Model 4) or 0.3 points (Model 5). Finally, in all models - even when registration and diaspora size are controlled for - external turnout is substantially higher in Slovenia and lower in Romania.

[Table 6 about here]

The current subsection provides a first piece of empirical evidence on how legal provisions for external voting and diaspora size affect external voting rates. Of course, given the limited number of observations and the resulting parsimonious operationalisation, caution

\footnotetext{
${ }^{16}$ The domestic voting rate corresponds to nationwide turnout after the removal of emigration from both the denominator and numerator. Its calculation is formally presented in Step 1 in Table 7.

${ }^{17}$ The Woolridge test for autocorrelation indicated that there is no need to control for autocorrelation $(\mathrm{p}=0.11)$.
} 
should be exercised in the interpretation. ${ }^{18}$ At the same time, this section supports the theoretical expectation that external voting rates tend to be always lower than domestic voting rates. Considering the magnitude of post-communist emigration flows, such low external turnout must significantly hurt nationwide turnout. This is further explored in the next sub-section.

\section{The Impact of Emigration on Voter Turnout}

After having ascertained the sources of variation in external voting rates, this subsection uses these rates (i.e. the estimated number of emigrant abstainers) to quantify the impact of emigration on the post-communist voter turnout. Following an approach commonly employed in the study of how demographic change affect voter turnout (e.g. Blais et al. 2004), I compute counterfactual turnout rates that would have been observed if the number of CEE-10 expatriates had not increased after the first democratic elections. The focus is on the sixth democratic election and the procedure is presented in detail in Table 7.

[Table 7 about here]

The calculated counterfactual voter turnout rates and their divergence from the real rates are presented in Table 8 . This divergence corresponds to the impact of emigration on the postcommunist turnout. The table shows that, had the number of post-communist emigrants remained stably low as in the first election, the average voter turnout rate in the sixth democratic election would have been higher by 2.1 percentage points (58.5 instead of 56.4). According to this estimate, emigration accounts for almost one tenth $(8.5 \%)$ of the post-communist decline in nationwide turnout.

Nevertheless, Table 8 also shows that the extent to which emigration contributes to the decline naturally varies across countries as it depends on the magnitude of the emigration outflows and the external turnout rates. In addition, given that post-communist emigration has strongly, and rather linearly, accelerated since 2004, what matters is also the timing of the

\footnotetext{
18 The current analysis is limited by the impossibility of incorporating more institutional factors that may affect external turnout such as the existence of special constituencies for non-resident citizens. Nevertheless, the results reported in Table 6 hold even when, instead of this article's dataset, OECD data is used (see Table 21 in the Electronic Appendix). Moreover, the theory advanced in Section 1 is also corroborated by the more qualitative exploration of the variation in external turnout, which is provided in Section 2 of the Electronic Appendix.
} 
elections. The later the sixth democratic legislative election was held, the stronger the magnitude of emigration and the larger its impact on voter turnout. Taking all these aspects into account, it is clear why the strongest 'emigration-related' decline can be observed in Lithuania (5 percentage points). Although Lithuania's external voting rates are average (cf. Ffigure 3), its emigration is strong and, the sixth democratic election was held only in 2012. At the other extreme, the effect is small to non-existent in the low-emigration countries: Hungary, the Czech Republic and, notably, Slovenia. In the last case, because of a strong degree of transnational participation by the Slovenian expatriates, the effect of emigration is practically nil despite the late timing of the sixth election.

[Table 8 about here]

It should be emphasised that the calculated external voter turnout figures are strongly conservative since, as mentioned above, they understate the real magnitude of CEE migration. If the pre-1989, clandestine, seasonal, and post-2004 free movement migration flows could be more accurately measured, the estimated contribution of emigration to the post-communist decline would be likely to exceed $10 \%$.

The logic of the diluting effect of emigration on voter turnout in CEE is reminiscent of a theme in Nikolai Vasilievich Gogol's world-famous novel 'Dead Souls'. Tsarist Russia taxed landowners as a function of the number of serfs they possessed. As the censuses were conducted only irregularly, serfs' mortality rates meant the official registers were fast becoming outdated. As a consequence, landowners had to pay taxes for deceased serfs they no longer possessed (i.e. the dead souls). In the post-communist case, it is emigration that renders voter registers outdated. The millions of CEE expatriates are fortunately not dead. Yet, they are distant, which, as this article theoretically underpins and empirically demonstrates, heavily matters for the probability of going to the polls. While citizens' voting rights are not altered, emigration fundamentally transforms the conditions for electoral participation. Even when the institutional setting for external voting is the most favourable, external voting costs are much higher than in the case of domestic voting. The rising number of 'distant souls' thus mechanically increase the magnitude of the post-communist voter turnout. In a way, it distorts electoral statistics (and 
their understanding), as the rising number of dead souls distorted fiscal statistics in the $19^{\text {th }}$ century Russia.

\section{Conclusion}

This article addressed the question of emigration and voter turnout. Drawing on the existing literature, it theorised why emigrants' propensity to vote in their homeland's elections, i.e. to participate transnationally, is typically low and, therefore, why emigration is likely to affect negatively nationwide turnout rates.

The empirical part first explored the magnitude of the post-communist emigration. It showed that, notably in the second decade of freedom, emigration rates strongly increased and the share of expatriates in the total Central and East European population exceeded $6 \%$. Subsequently, I overviewed the CEE legal provisions for voter registration and external voting. The overwhelmingly inclusive character of voter registration, i.e. its automaticity and lifelong durability, entails that, in Central and Eastern Europe, expatriates do matter for national turnout rates. Wherever they are on the globe, expatriates are included in the official turnout statistics. The empirical analyses corroborated that the extent to which post-communist expatriates participate in domestic elections depends, to a large extent, on legal provisions for external voting, of which registration rules, and diaspora size. At the same time, post-communist transnational participation is in all countries and elections much weaker than domestic participation. Emigration thus significantly contributed to the post-communist decline in voter turnout. According to my estimates, the rising number of 'distant souls' and their low propensity to vote account for, at least, $8.5 \%$ of the decline in the first six democratic elections. The magnitude of this negative effect may continue to increase as emigration has kept rising.

Moreover, some studies suggest that, in addition to the direct effects studied here, emigration can reduce voter turnout, more indirectly by affecting the domestic electorate that did not emigrate. Godman and Hiskey (2008) find that in Mexico emigration reduces electoral participation of 'those left behind' since they increasingly rely on more the transnational ties (and remittances) instead of formal institutions. And other studies also showed that emigrants (and also emigrant returnees) have an influence on preferences, values, and behaviours of citizens back home (e.g. Chauvet et Mercier 2014, Péréz-Armendariz 2014, Omar-Mahmoud 
et al. 2015). Future studies should explore this potential additional effect in the CEE-10 through a micro-level analysis.

In any case, if policy-makers in post-communist democracies and other nations recording high emigration rates are worried by falling nationwide turnout, they should, among other measures, tackle legal provisions for external voting. They can either, like Ireland, disenfranchise expatriates or, like Slovenia, deploy much larger efforts to mobilise their diasporas and facilitate external voting. The first remedy will be more efficient (eliminating the problem of emigration all together) but, at the same time, will clash with the global trend of democratic deepening and expatriates' enfranchisement. Enhancing mobilisation and facilitating external voting will have a more uncertain effect but will be congruent with the current zeitgeist, which recognises expatriates as full-fledged members of home country's political community.

\section{References}

Bauböck, Rainer. 2003. "Towards a Political Theory of Migrant Transnationalism." International Migration Review 37 (3): 700-723.

Beck, Nathaniel. 2001. "TIME-SERIES-CROSS-SECTION DATA: What Have We Learned in the Past Few Years?" Annual Review of Political Science 4 (1): 271-293.

Bertelsmann Stiftung. 2009. BTI 2010: Slovenia Country Report. Gütersloh: Bertelsmann Stiftung.

Blais, André. 2006. "What Affects Voter Turnout?" Annual Review of Political Science 9 (1): 111-125.

Blais, André, Elisabeth Gidengil, and Neil Nevitte. 2004. "Where Does Turnout Decline Come From?" European Journal of Political Research 43 (2): 221-236.

Braconnier, Celine, and Jean-Yves Dormagen. 2007. La démocratie de l'abstention : aux origines de la démobilisation en milieu populaire [Democracy of Abstention: The Origins of demobilisation in the Popular Milieu]. Paris: Gallimard.

Campbell, Angus, Philip E. Converse, Warren E. Miller, and Donald E. Stokes. 1960. The American Voter. Chicago: University of Chicago Press.

Chauvet, Lisa, and Marion Mercier. 2014. "Do Return Migrants Transfer Political Norms to Their Origin Country? Evidence from Mali." Journal of Comparative Economics 42 (3): 630-651.

Comşa, Mircea. 2015. “Turnout Decline in Romanian National Elections: Is It That Big?" Studia UBB Sociologia 60 (2): 59-83.

Dobreva, Alina. 2013. Access to Electoral Rights: Bulgaria. EUDO Citizenship Observatory. Badia Fiesolana, San Domenico di Fiesole (FI), Italy: Robert Schuman Centre for Advanced Studies.

Downs, Anthony. 1957. An Economic Theory of Democracy. Harper.

Dumont, Jean-Christophe, and Georges Lemaître. 2005. "Georges, Counting Immigrants and Expatriates in OECD Countries: A New Perspective." OECD Social, Employment and Migration Working Papers 25. OECD Publishing. 
Franklin, Mark N. 2005. "You Want to Vote Where Everybody Knows Your Name: Anonymity, Expressive Engagement, and Turnout Among Young Adults." Paper presented at the Annual meeting of the APSA, Washington D.C., September.

Gherghina, Sergiu, and Sergiu Miscoiu. 2013. "The Failure of Cohabitation: Explaining the 2007 and 2012 Institutional Crises in Romania." East European Politics \& Societies 27 (4): 668-684.

Gödri, Irén, Béla Soltész, and Boróka Bodacz-Nagy. 2013. Dynamic Historical Analysis of Longer Term Migratory, Labour Market and Human Capital Processes in Hungary. Country report developed within the project 'SEEMIG Managing Migration and Its Effects Transnational Actions Towards Evidence Based Strategies'.

Goździak, Elżbieta M. 2014. "Polish Migration after the Fall of the Iron Curtain." International Migration 52 (1): 1-3.

Green, Donald P., and Ron Shachar. 2000. "Habit Formation and Political Behaviour: Evidence of Consuetude in Voter Turnout." British Journal of Political Science 30 (4): 561573.

Green, Phil. 2007. “Entitlement to Vote.” In Voting from Abroad: The International Idea Handbook, edited by Andrew Ellis, Carlos Navarro, Isabel Morales, Maria Gratschew, and Nadja Braun, 89-103. Stockholm: IDEA.

Goodman, Gary L., and Jonathan T. Hiskey. 2008. "Exit without Leaving: Political Disengagement in High Migration Municipalities in Mexico." Comparative Politics 40 (2): 169-188.

Highton, Benjamin. 2000. "Residential Mobility, Community Mobility, and Electoral Participation.” Political Behavior 22 (2): 109-120.

Knott, Eleanor. 2015. "Extra-Territorial Voting Practices and the Asymmetry of Charisma: Basescu and His Moldovan Constituents." Paper presented at the Annual meeting of the MPSA, Chicago, March.

Kostadinova, Tatiana. 2003. "Voter Turnout Dynamics in post-Communist Europe." European Journal of Political Research 42 (6): 741-759. doi:10.1111/1475-6765.00102.

Kostelka, Filip. 2014. "The State of Political Participation in Post-Communist Democracies: Low but Surprisingly Little Biased Citizen Engagement." Europe-Asia Studies 66 (6): 945-968.

Kostelka, Filip. 2015. "To Mobilise and Demobilise: The Puzzling Decline of Voter Turnout in Post-Communist Democracies." PhD diss., Paris, Institut d'études politiques.

Lafleur, Jean-Michel, and Leticia Calderón Chelius. 2011. "Assessing Emigrant Participation in Home Country Elections: The Case of Mexico's 2006 Presidential Election." International Migration 49 (3): 99-124.

Lazarsfeld, Paul Felix, Bernard Berelson, and Hazel Gaudet. 1948. The People's Choice: How the Voter Makes Up His Mind in a Presidential Campaign. Columbia University Press.

Navarro, Carlos, Isabel Morales, and Maria Gratschew. 2007. "External Voting: A Comparative Overview." In Voting from Abroad: The International Idea Handbook, edited by Andrew Ellis, Carlos Navarro, Isabel Morales, Maria Gratschew, and Nadja Braun, 11-34. IDEA.

Nohlen, Dieter, and Philip Stöver, eds. 2010. Elections in Europe: A Data Handbook. Baden-Baden, Germany: Nomos Verlagsgesellschaft.

Nohlen, Dieter, and Florian Grotz. 2007. "The Legal Framework and an Overview of Electoral Legislation." In Voting from Abroad: The International Idea Handbook, edited by Andrew Ellis, Carlos Navarro, Isabel Morales, and Maria Gratschew, 65-75. IDEA. 
Omar Mahmoud, Toman, Hillel Rapoport, Andreas Steinmayr, and Christoph Trebesch. 2013. The Effect of Labor Migration on the Diffusion of Democracy: Evidence from a Former Soviet Republic. SSRN Scholarly Paper ID 2327441. Rochester, NY: Social Science Research Network.

OSCE. 2001. Republic of Bulgaria: Parliamentary Elections 17 June 2001. Final Report. Warsaw: OSCE/ODIHR.

OSCE. 2012. Republic of Slovenia: Early Elections of the National Assembly 4 December 2011. OSCE/ODIHR Election Assessment Mission Final Report. Warsaw: OSCE/ODIHR.

OSCE. 2015. Republic of Bulgaria: Early Parliamentary Elections 5 October 2014. OSCE/ODIHR Limited Election Observation Mission Final Report. Warsaw: OSCE/ODIHR.

Østergaard-Nielsen, Eva. 2003. "The Politics of Migrants' Transnational Political Practices." International Migration Review 37 (3): 760-786.

Pacek, Alexander C, Grigore Pop-Eleches, and Joshua A. Tucker. 2009. "Disenchanted or Discerning: Voter Turnout in Post-Communist Countries." Journal of Politics 71 (2): 473491.

Pérez-Armendáriz, Clarisa. 2014. "Cross-Border Discussions and Political Behavior in Migrant-Sending Countries." Studies in Comparative International Development 49 (1): 6788.

Pytlikova, Maria. 2006. "Migration into OECD Countries 1990-2000." In Immigration and the Transformation of Europe, edited by Craig A. Parsons and Timothy M. Smeeding. Cambridge University Press.

Rosenstone, Steven J., and John Mark Hansen. 1993. Mobilisation, Participation, and Democracy in America. London: Longman.

Squire, Peverill, Raymond E. Wolfinger, and David P. Glass. 1987. "Residential Mobility and Voter Turnout." American Political Science Review 81 (01): 45-65.

Trampuš, Jure. 2007. “'Kaj Bo, Če Bo Tisoč Glasov Razlike?.” Mladina, October 26.

Verba, Sidney, and Norman Nie. 1972. Participation in America: Political Democracy and Social Equality. New York: Harper and Row.

Voicu, Bogdan, and Mircea Comşa. 2014. "Immigrants' Participation in Voting: Exposure, Resilience, and Transferability." Journal of Ethnic and Migration Studies 40 (10): $1572-1592$.

Wolfinger, Raymond Edwin, and Steven J. Rosenstone. 1980. Who Votes?. New Haven: Yale University Press.

\section{Appendix}

[Table 9 about here] 
Table 1 Sources of Emigration Data by Destination

\begin{tabular}{|c|c|c|}
\hline Destination & Sources & Type of Data \\
\hline $\begin{array}{l}\text { Western } \\
\text { Europe }\end{array}$ & $\begin{array}{l}\text { Holland, Dawn, Tatiana Fic, Ana Rincon-Aznar, Lucy Stokes, and Pavel Paluchowski. 2011. Labour Mobility within the EU - } \\
\text { The Impact of Enlargement and the Functioning of the Transitional Arrangements - Final Report. London: National Institute } \\
\text { of Economic and Social Research, United Kingdom. } \\
\text { Complemented for 2010-2012 with Duszczyk, Maciej, and Kamil Matuszczyk. 2014. Migration in the } 21 \text { st Century from the } \\
\text { Perspective of CEE Countries - an Opportunity or a Threat? Warsaw: Central and Eastern Europe Development Institute. } \\
\text { Note: The latter study is compatible and draws on the former study. }\end{array}$ & $\begin{array}{l}\text { Original estimations } \\
\text { combining Eurostat and } \\
\text { OECD data. }\end{array}$ \\
\hline USA & $\begin{array}{l}\text { U.S. Immigration and Naturalization Service. 2002. Statistical Yearbook of the Immigration and Naturalization Service } 2000 . \\
\text { Washington D.C.: U.S. Government Printing Office. } \\
\text { United States. Department of Homeland Security. 2011. Yearbook of Immigration Statistics: 2010. Washington D.C.: U.S. } \\
\text { Government Printing Office. United States. } \\
\text { Department of Homeland Security. 2013. Yearbook of Immigration Statistics: 2012. Washington D.C.: U.S. Government } \\
\text { Printing Office. }\end{array}$ & $\begin{array}{l}\text { Records of legal } \\
\text { permanent residents } \\
\text { (without U.S. citizenship) }\end{array}$ \\
\hline $\begin{array}{l}\text { Turkey } \\
\text { (Bulgarians } \\
\text { only) }\end{array}$ & $\begin{array}{l}\text { Global Bilateral Migration Database, World Bank Group and Ç. Özden, C. Parsons, M. Schiff and T. L. Walmsley (2011) } \\
\text { "Where on Earth is Everybody? The Evolution of Global Bilateral Migration, 1960-2000", World Bank Economic Review } \\
\text { 25(1):12-56. Updated version from } 2011 \text { with year 2010, downloaded from http://data.worldbank.org/, accessed October } 7 \text {, } \\
\text { 2014). } \\
\text { Note: WB statistics are based on origin and not on citizenship. Therefore, the total estimate was corrected by an estimate of the } \\
\text { number of Bulgarian emigrants living in Turkey who kept Bulgarian citizenship (about } 380000 \text { at the end of the period) obtained } \\
\text { from Smilov, Daniel, and Elena Jileva. 2010. Country Report: Bulgaria. EUDO Citizenship Observatory. Badia Fiesolana, San } \\
\text { Domenico di Fiesole (FI), Italy: Robert Schuman Centre for Advanced Studies, p. } 19 \text {. }\end{array}$ & $\begin{array}{l}\text { Census and population } \\
\text { register records }\end{array}$ \\
\hline $\begin{array}{l}\text { Czech } \\
\text { Republic } \\
\text { (Slovaks } \\
\text { only) }\end{array}$ & $\begin{array}{l}\text { Cizinci podle státniho občanství } k 31 \text {. 12. - územní srovnání [Foreigners by citizenship as at } 31 \text { December - territorial } \\
\text { comparison]. Records produced by the Czech Alien Police, data downloaded from the website of the Czech Statistical Office, } \\
\text { www.czso.cz, accessed November } 3,2014 \text {. }\end{array}$ & Police records \\
\hline $\begin{array}{l}\text { Moldova } \\
\text { (Romanians } \\
\text { only) }\end{array}$ & $\begin{array}{l}\text { Panainte, Sergiu, Victoria Nedelciuc, and Ovidiu Voicu. 2013. Redobândirea Cetăteniei Române: O politică ce Capăcă Viziune } \\
\text { ? [Romanian Citizenship: a policy that acquires vision?]. Bucurest: Fundatia Soros Romania. }\end{array}$ & $\begin{array}{c}\text { Records of Romania's } \\
\text { National Citizenship } \\
\text { Authority }\end{array}$ \\
\hline
\end{tabular}


Table 2 The Estimated Number of CEE Citizens Living in the Principal Emigration Destinations 1990-2012 (Absolute Numbers)

Bulgaria Czech Republic Estonia Hungary Latvia Lithuania Poland Romania Slovakia Slovenia Total

\begin{tabular}{|c|c|c|c|c|c|c|c|c|c|c|c|}
\hline 1990 & 348313 & 31343 & 13461 & 80469 & 5156 & 10075 & 403909 & 117719 & 10868 & 27982 & 1049295 \\
\hline 1991 & 353437 & 33560 & 13999 & 82738 & 5761 & 11099 & 431503 & 143708 & 12634 & 28349 & 1116788 \\
\hline 1992 & 359082 & 35863 & 14727 & 84784 & 6751 & 12393 & 465587 & 168679 & 14591 & 28729 & 1191186 \\
\hline 1993 & 364807 & 38111 & 15472 & 86624 & 8049 & 13946 & 502200 & 193368 & 16703 & 29156 & 1268435 \\
\hline 1994 & 370588 & 40213 & 16320 & 88260 & 9504 & 15721 & 539207 & 216562 & 35923 & 29604 & 1361901 \\
\hline 1995 & 377293 & 42427 & 17122 & 89923 & 10919 & 17696 & 562186 & 241892 & 61846 & 30056 & 1451361 \\
\hline 1996 & 384381 & 44791 & 18023 & 91877 & 12496 & 20089 & 587314 & 268913 & 75802 & 30524 & 1534209 \\
\hline 1997 & 392295 & 47153 & 18952 & 93603 & 14037 & 22327 & 608913 & 296491 & 81403 & 30983 & 1606157 \\
\hline 1998 & 395034 & 49224 & 20234 & 94246 & 16122 & 24818 & 611164 & 299712 & 80806 & 31849 & 1623210 \\
\hline 1999 & 406429 & 50985 & 21050 & 98344 & 17730 & 27279 & 644176 & 347243 & 82457 & 32433 & 1728126 \\
\hline 2000 & 424081 & 56760 & 22186 & 99288 & 19653 & 32446 & 675784 & 397591 & 89354 & 32792 & 1849935 \\
\hline 2001 & 459360 & 67301 & 24700 & 105797 & 22000 & 39307 & 708035 & 464301 & 102617 & 32957 & 2026375 \\
\hline 2002 & 500182 & 78340 & 27007 & 106928 & 24738 & 53234 & 736264 & 555886 & 120897 & 32657 & 2236133 \\
\hline 2003 & 545890 & 82145 & 30008 & 107355 & 29374 & 63275 & 804347 & 726231 & 139582 & 34864 & 2563071 \\
\hline 2004 & 584981 & 73550 & 32481 & 103578 & 30503 & 80913 & 875625 & 906393 & 128363 & 33963 & 2850350 \\
\hline 2005 & 624742 & 81395 & 37545 & 110070 & 39736 & 117259 & 1030512 & 1080041 & 159722 & 36289 & 3317311 \\
\hline 2006 & 674854 & 107673 & 41125 & 128073 & 60381 & 163556 & 1317916 & 1315566 & 182052 & 37853 & 4029049 \\
\hline 2007 & 749034 & 125907 & 49249 & 151619 & 67117 & 188376 & 1610273 & 1852642 & 232204 & 39398 & 5065819 \\
\hline 2008 & 841327 & 124734 & 48310 & 169403 & 84957 & 222844 & 1786342 & 2155102 & 234716 & 39023 & 5706758 \\
\hline 2009 & 871032 & 118742 & 63540 & 175339 & 90692 & 216370 & 1795641 & 2376721 & 255034 & 41990 & 6005101 \\
\hline 2010 & 894523 & 120683 & 66962 & 187193 & 107207 & 237927 & 1903847 & 2513440 & 251673 & 42886 & 6326342 \\
\hline 2011 & 912309 & 107052 & 65029 & 174212 & 112346 & 234364 & 1704300 & 2678005 & 259257 & 59147 & 6306020 \\
\hline 2012 & 929873 & 108677 & 68227 & 185054 & 128436 & 254924 & 1804300 & 2846487 & 261857 & 59420 & 6647255 \\
\hline
\end{tabular}

Note: The Emigration destinations considered are EU-15, the USA, Turkey (for Bulgarians), Moldova (for Romanians) and the Czech Republic (for Slovaks). The table aggregates estimates presented in Electronic Appendix (EA) Tables 13, 14, 15, 16 and 17. 
Table 3 The Estimated Shares of the CEE Voting Age Populations Residing Abroad

\begin{tabular}{ccccccc}
\multirow{2}{*}{ Bulgaria } & 1990 & 1991 & 1994 & 1997 & 2001 & 2005 \\
& 4.3 & 4.5 & 4.6 & 4.9 & 5.8 & 8.0 \\
\hline Czech & 1990 & 1992 & 1996 & 1998 & 2002 & 2006 \\
Republic & 0.4 & 0.4 & 0.5 & 0.5 & 0.9 & 1.2 \\
\hline \multirow{2}{*}{ Estonia } & 1992 & 1995 & 1999 & 2003 & 2007 & 2011 \\
& 1.9 & 1.9 & 2.2 & 3.1 & 4.9 & 6.9 \\
\hline \multirow{2}{*}{ Hungary } & 1990 & 1994 & 1998 & 2002 & 2006 & 2010 \\
& 0.9 & 1.0 & 1.0 & 1.2 & 1.4 & 2.1 \\
\hline \multirow{2}{*}{ Latvia } & 1993 & 1995 & 1998 & 2002 & 2006 & 2010 \\
& 0.6 & 0.7 & 1.0 & 1.7 & 3.6 & 6.4 \\
\hline \multirow{2}{*}{ Lithuania } & 1992 & 1996 & 2000 & 2004 & 2008 & 2012 \\
& 0.4 & 0.7 & 1.1 & 1.8 & 7.4 & 9.9 \\
\hline \multirow{2}{*}{ Poland } & 1989 & 1991 & 1993 & 1997 & 2001 & 2005 \\
& $\mathrm{NA}$ & 1.4 & 1.6 & 1.9 & 2.2 & 3.0 \\
\hline \multirow{2}{*}{ Romania } & 1990 & 1992 & 1996 & 2000 & 2004 & 2008 \\
& 0.6 & 0.9 & 1.4 & 2.0 & 4.4 & 11.5 \\
\hline \multirow{2}{*}{ Slovakia } & 1990 & 1992 & 1994 & 1998 & 2002 & 2006 \\
& 0.3 & 0.3 & 0.8 & 1.6 & 2.3 & 3.6 \\
\hline \multirow{2}{*}{ Slovenia } & 1992 & 1996 & 2000 & 2004 & 2008 & 2011 \\
& 1.7 & 1.8 & 1.9 & 1.9 & 2.1 & 2.3 \\
\hline Average & 1.2 & 1.4 & 1.6 & 2.1 & 3.5 & 5.5
\end{tabular}

Note: This table based on the estimated number of CEE citizens in voting age living in the principal emigration destinations (see Table 2), their age distribution described in Section 2, and the size of CEE electorates (EA Table 19). 
Table 4 Provisions for External Voting in CEE

\begin{tabular}{|c|c|c|c|c|}
\hline Country & $\begin{array}{l}\text { Introduction of } \\
\text { External Voting }\end{array}$ & Voting Method $^{2}$ & $\begin{array}{c}\text { Registration } \\
\text { Deadline for } \\
\text { External Voting }\end{array}$ & $\begin{array}{c}\text { Count of External } \\
\text { Votes }^{2}\end{array}$ \\
\hline Bulgaria & 1994 & Personal & No deadline & $\begin{array}{l}\text { Assimilated in } \\
\text { the nationwide } \\
\text { result since } 2005^{3}\end{array}$ \\
\hline $\begin{array}{c}\text { Czech } \\
\text { Republic }\end{array}$ & 2002 & Personal & 40 days & $\begin{array}{l}\text { Assimilated in a } \\
\text { constituency } \\
\text { selected by lot }\end{array}$ \\
\hline Estonia & 1992 & $\begin{array}{l}\text { Mixed (Personal, } \\
\text { Postal since 1992, } \\
\text { E-Voting since the } \\
\text { election of 2007). }\end{array}$ & $\begin{array}{c}30 \text { days } \\
\text { (no deadline for } \\
\text { electronic } \\
\text { voting) }\end{array}$ & $\begin{array}{l}\text { Assimilated in } \\
\text { the constituency } \\
\text { of former } \\
\text { residence }\end{array}$ \\
\hline Hungary & 2006 & $\begin{array}{l}\text { Mixed (Personal, } \\
\text { Postal since 2013) }\end{array}$ & $\begin{array}{c}8 \text { days } \\
\text { (personal) } \\
10 \text { days } \\
\text { (postal) }\end{array}$ & $\begin{array}{l}\text { Assimilated in } \\
\text { the nation-wide } \\
\text { result since } 2010^{4}\end{array}$ \\
\hline Latvia & 1992 & $\begin{array}{l}\text { Mixed (Personal, } \\
\text { Postal since the } \\
\text { election of 1998) }\end{array}$ & 21 days & $\begin{array}{l}\text { Assimilated in } \\
\text { the Riga } \\
\text { constituency }\end{array}$ \\
\hline Lithuania & 1992 & $\begin{array}{l}\text { Mixed (Personal, } \\
\text { Postal) }\end{array}$ & 15 days & $\begin{array}{l}\text { Assimilated in } \\
\text { the Vilnius } \\
\text { constituency }\end{array}$ \\
\hline Poland & 1990 & $\begin{array}{l}\text { Mixed (Personal, } \\
\text { Postal since 2011) }\end{array}$ & $\begin{array}{c}3 \text { days } \\
\text { (personal) } \\
15 \text { days (postal) }\end{array}$ & $\begin{array}{l}\text { Assimilated in } \\
\text { the Central } \\
\text { Warsaw } \\
\text { Constituency }\end{array}$ \\
\hline Romania & 1992 & Personal & No deadline & $\begin{array}{c}\text { Counted } \\
\text { separately in a } \\
\text { special } \\
\text { constituency } \\
\text { since } 2008^{5}\end{array}$ \\
\hline Slovakia & 2006 & Postal & 50 days & $\begin{array}{l}\text { Assimilated in } \\
\text { the nation-wide } \\
\text { result }\end{array}$ \\
\hline Slovenia & 1992 & $\begin{array}{l}\text { Mixed (Personal, } \\
\text { Postal) }\end{array}$ & $\begin{array}{l}30 \text { days (but, de } \\
\text { facto, } \\
\text { automatic) for } \\
\text { postal voting, } \\
15 \text { days } \\
\text { (personal) }\end{array}$ & $\begin{array}{l}\text { Assimilated in } \\
\text { the constituency } \\
\text { of former } \\
\text { residence }\end{array}$ \\
\hline
\end{tabular}

Note: Data as of 2014. Sources: EUDO Citizenship Observatory Reports (http://eudo-citizenship.eu/countryprofiles, accessed 30/05/2015) and questionnaires sent to the national electoral authorities. ${ }^{1}$ Each entry corresponds to the year of the first democratic legislative election in which external voting was allowed. ${ }^{2}$ Unless specified otherwise, the legislation has been in place since the introduction of external voting. ${ }^{3}$ Until the election of 2001, the Bulgarian external votes were assimilated in four regional constituencies (cf. Dobreva 2013, 14). ${ }^{4}$ Until the election of 2010, the Hungarian external votes were assimilated in one of the regional constituencies. ${ }^{5}$ Before the election of 2008 , Romanian external votes were assimilated in the Bucharest constituency. ${ }^{6}$ If the 
constituency of former residence (of voters themselves or one of their parents) cannot be determined, voters may choose the constituency in which they vote.

Table 5 Quantitative Variables - Descriptive Statistics

\begin{tabular}{lccccc}
\hline Variable & $\mathrm{N}$ & Mean & SD & Min & Max \\
\hline $\begin{array}{l}\text { External Turnout } \\
\text { (dependent variable) }\end{array}$ & 27 & 9.31 & 7.71 & 1.10 & 32.10 \\
$\begin{array}{l}\text { Registration } \\
\text { (days before election) }\end{array}$ & 27 & 15.59 & 17.67 & 0 & 50 \\
$\begin{array}{l}\text { Electorate Abroad } \\
\text { (as \% of total electorate) }\end{array}$ & 27 & 5.23 & 3.39 & 0.90 & 13.70 \\
Domestic Turnout & 27 & 56.63 & 7.65 & 41.74 & 69.70 \\
\hline
\end{tabular}


Table 6 OLS Regression Analysis of External Voting Rates

\begin{tabular}{|c|c|c|c|c|c|}
\hline & $\begin{array}{c}\text { Model } 1 \\
\text { (Registration) }\end{array}$ & $\begin{array}{l}\text { Model } 2 \\
\text { (Electorate } \\
\text { Abroad) }\end{array}$ & $\begin{array}{l}\text { Model } 3 \\
\text { (Full } \\
\text { Model) }\end{array}$ & $\begin{array}{l}\text { Model } 4 \\
\text { (PCSE) }\end{array}$ & $\begin{array}{c}\text { Model } 5 \\
\text { (Fixed } \\
\text { Effects \& } \\
\text { PCSE) }\end{array}$ \\
\hline $\begin{array}{l}\text { Registration } \\
\text { (days before } \\
\text { election) }\end{array}$ & $\begin{array}{c}-0.14 \\
(0.05)^{* *}\end{array}$ & & $\begin{array}{l}-0.11 \\
(0.04)^{*}\end{array}$ & $\begin{array}{l}-0.11 \\
(0.03)^{* *}\end{array}$ & \\
\hline $\begin{array}{l}\text { Electorate Abroad } \\
\text { (as \% of total } \\
\text { electorate) }\end{array}$ & & $\begin{array}{c}0.90 \\
(0.28)^{* *}\end{array}$ & $\begin{array}{c}0.71 \\
(0.26)^{*}\end{array}$ & $\begin{array}{c}0.71 \\
(0.11)^{* * *}\end{array}$ & $\begin{array}{c}0.45 \\
(0.11)^{* * *}\end{array}$ \\
\hline Domestic Turnout & $\begin{array}{c}0.29 \\
(0.11)^{*}\end{array}$ & $\begin{array}{c}0.35 \\
(0.11)^{* *}\end{array}$ & $\begin{array}{c}0.36 \\
(0.10)^{* *}\end{array}$ & $\begin{array}{c}0.36 \\
(0.04)^{* * *}\end{array}$ & $\begin{array}{c}0.33 \\
(0.06)^{* * *}\end{array}$ \\
\hline Slovenia & $\begin{array}{c}19.06 \\
(3.03)^{* * *}\end{array}$ & $\begin{array}{l}21.46 \\
(3.00)^{* * *}\end{array}$ & $\begin{array}{c}20.57 \\
(2.72)^{* * *}\end{array}$ & $\begin{array}{l}20.57 \\
(2.19)^{* * *}\end{array}$ & $\begin{array}{c}14.23 \\
(2.51)^{* * *}\end{array}$ \\
\hline Romania & $\begin{array}{l}-4.66 \\
(2.83)\end{array}$ & $\begin{array}{l}-5.99 \\
(2.88)^{*}\end{array}$ & $\begin{array}{l}-6.80 \\
(2.61)^{*}\end{array}$ & $\begin{array}{c}-6.80 \\
(1.42)^{* * *}\end{array}$ & $\begin{array}{c}-10.04 \\
(1.51)^{* * *}\end{array}$ \\
\hline $\begin{array}{l}\text { Remaining Country } \\
\text { Dummies }\end{array}$ & No & No & No & No & Yes \\
\hline Constant & $\begin{array}{l}-6.04 \\
(6.53)\end{array}$ & $\begin{array}{l}-16.21 \\
(7.14)^{*}\end{array}$ & $\begin{array}{l}-14.19 \\
(6.48)^{*}\end{array}$ & $\begin{array}{l}-14.19 \\
(2.06)^{* * *}\end{array}$ & $\begin{array}{l}-7.05 \\
(4.76)\end{array}$ \\
\hline Observations & 27 & 27 & 27 & 27 & 27 \\
\hline$R^{2}$ & 0.776 & 0.786 & 0.835 & 0.835 & 0.964 \\
\hline
\end{tabular}


Table 7 Formalised Calculation of the Counterfactual Voter Turnout Rates

Step 1:

$$
\begin{aligned}
& \mathrm{Te}_{\mathrm{i}}=\mathrm{Re}_{\mathrm{i}} * \mathrm{Se}_{\mathrm{i}} \\
& \mathrm{Rd}_{\mathrm{i}}=\left(\mathrm{T}_{\mathrm{i}}-\mathrm{Te}_{\mathrm{i}}\right) / \mathrm{Sd}_{\mathrm{i}}
\end{aligned}
$$

In the first step, emigrants' contribution $\left(\mathrm{Te}_{\mathrm{i}}\right)$ is deduced from the nationwide turnout rate $\left(T_{i}\right)$ in order to generate a precise estimate of the 'purely' domestic voting rate $\left(R_{i}\right)$. This is done as follows: First, the external voting turnout rate $\left(\mathrm{Re}_{\mathrm{i}}\right)$ is multiplied by the emigrant's share in the total electorate $\left(\mathrm{Se}_{\mathrm{i}}\right)$. Second, the resulting product $\left(\mathrm{Te}_{\mathrm{i}}\right)$ is subtracted from the nationwide turnout $\left(\mathrm{T}_{\mathrm{i}}\right)$ and divided by the share of domestic citizens in the total electorate $\left(\mathrm{Sd}_{\mathrm{i}}\right)$.

$$
\text { Step 2: } \quad \operatorname{Tdf}_{\mathrm{i}}=\mathrm{Rd}_{\mathrm{i}} * \mathrm{Sd}_{1}
$$

In the second step, I calculate the 'domestic contribution' to the counterfactual voter turnout rate $\left(\mathrm{Tdf}_{\mathrm{i}}\right)$ by multiplying the purely domestic turnout rate $\left(\mathrm{Rd}_{\mathrm{i}}\right)$ from Step 1 and the share of domestic citizens in the total electorate from the first democratic election $\left(\operatorname{Sd}_{1}\right)$.

Step 3:

$$
\begin{aligned}
\mathrm{Rea}_{\mathrm{i}} & =\mathrm{Re}_{\mathrm{i}}-\mathrm{b} *\left(\mathrm{Se}_{\mathrm{i}}-\mathrm{Se}_{1}\right) \\
\mathrm{Tef}_{\mathrm{i}} & =\mathrm{Rea}_{\mathrm{i}} * \mathrm{Se}_{1}
\end{aligned}
$$

Before calculating the 'external contribution' to the counterfactual voter turnout rate $\left(\right.$ Tef $\left._{\mathrm{i}}\right)$, which is the main purpose of Step 3, it should be reminded that the theory in Section 1 and the empirical analysis in Table 5 show that external voting rates depend on diaspora size (the larger the share of emigrants in the total electorate, the higher external turnout). Therefore, as the current calculation of counterfactual voter turnout is based on the diaspora size from the first election, which is smaller than the real diaspora size observed in later elections, the real external voting rate $\left(\mathrm{Re}_{\mathrm{i}}\right)$ needs to be adjusted. This is done by reducing the real rate $\left(\mathrm{Re}_{\mathrm{i}}\right)$ by the product of the effect of diaspora size (b) and the difference between the real share $\left(\mathrm{Se}_{\mathrm{i}}\right)$ and the counterfactual share $\left(\mathrm{Se}_{1}\right)$ of emigrants in the total electorate. To operationalize the effect of diaspora size, I rely on the regression coefficient of the variable Electorate Abroad from Model 5 in Table 5 (i.e. 0.3). As an aside, this adjustment is a theoretical imperative but, in practice, it reduces the calculated counterfactual voter turnout in the CEE-10 (i.e. the final outcome after Step 4) by a virtually negligible 0.01 percentage points on average.

Subsequently, the 'external contribution' $\left(\mathrm{Tef}_{\mathrm{i}}\right)$ is obtained by multiplying the product of the adjusted external voting rate (Rea $)$ and the share of expatriated citizens in the total electorate in the first democratic elections $\left(\mathrm{Se}_{1}\right)$.

$$
\text { Step 4: } \quad \mathrm{Tcf}_{\mathrm{i}}=\mathrm{Td}_{\mathrm{i}}+\mathrm{Te}_{\mathrm{i}}
$$

Finally, the addition of the domestic and external contributions yields the counterfactual voter turnout rate $\left(\mathrm{Tcf}_{\mathrm{i}}\right)$ that would be observed in each election if nothing changed except the level of emigration that would be kept constant from the first democratic election onwards. 
Table 8 Effect of Emigration on Voter Turnout in the 6th Democratic Election

\begin{tabular}{lcccc}
\hline \multicolumn{1}{c}{ Country } & Election Year & $\begin{array}{c}\text { Official } \\
\text { Voter Turnout }\end{array}$ & $\begin{array}{c}\text { Counterfactual } \\
\text { Voter Turnout }\end{array}$ & $\begin{array}{c}\text { Effect of } \\
\text { Emigration on } \\
\text { Voter Turnout }\end{array}$ \\
\hline Bulgaria & 2005 & 55.8 & 57.5 & -1.7 \\
Czech Republic & 2006 & 64.5 & 65.0 & -0.5 \\
Estonia & 2011 & 63.5 & 66.2 & -2.7 \\
Hungary & 2010 & 64.4 & 65.1 & -0.7 \\
Latvia & 2010 & 62.6 & 65.7 & -3.0 \\
Lithuania & 2012 & 52.9 & 58.0 & -5.0 \\
Poland & 2005 & 40.6 & 41.2 & -0.6 \\
Romania & 2008 & 39.2 & 43.9 & -4.7 \\
Slovakia & 2006 & 54.7 & 56.5 & -1.8 \\
Slovenia & 2011 & 65.6 & 65.8 & -0.1 \\
\hline Average & 2008.4 & 56.4 & 58.5 & -2.1 \\
\hline
\end{tabular}

Note: The calculation of the counterfactual voter turnout is described in Table 7. 
Table 9 Votes from Abroad 1989 - 2012 (Absolute Numbers)

\begin{tabular}{|c|c|c|c|c|c|c|c|c|}
\hline $\begin{array}{l}\text { Election/ } \\
\text { Country }\end{array}$ & 1 & 2 & 3 & 4 & 5 & 6 & 7 & 8 \\
\hline \multirow{2}{*}{ Bulgaria } & 1990 & 1991 & 1994 & 1997 & 2001 & 2005 & 2009 & \\
\hline & 0 & 0 & 20304 & 26856 & 64822 & 77020 & 156195 & \\
\hline \multirow{2}{*}{$\begin{array}{c}\text { Czech } \\
\text { Republic }\end{array}$} & 1990 & 1992 & 1996 & 1998 & 2002 & 2006 & 2010 & \\
\hline & 0 & 0 & 0 & 0 & 3763 & 6744 & 8222 & \\
\hline \multirow{2}{*}{ Estonia } & 1992 & 1995 & 1999 & 2003 & 2007 & 2011 & & \\
\hline & 9349 & 6647 & 3294 & 1915 & 2751 & 8253 & & \\
\hline \multirow{2}{*}{ Hungary } & 1990 & 1994 & 1998 & 2002 & 2006 & 2010 & & \\
\hline & 0 & 0 & 0 & 0 & 6679 & 6761 & & \\
\hline \multirow{2}{*}{ Latvia } & 1993 & 1995 & 1998 & 2002 & 2006 & 2010 & 2011 & \\
\hline & NA & NA & 10080 & 7490 & 7580 & 12778 & 14210 & \\
\hline \multirow{2}{*}{ Lithuania } & 1992 & 1996 & 2000 & 2004 & 2008 & 2012 & & \\
\hline & NA & 4305 & 5623 & 9313 & 10345 & 13061 & & \\
\hline \multirow{2}{*}{ Poland } & 1989 & 1991 & 1993 & 1997 & 2001 & 2005 & 2007 & 2011 \\
\hline & NA & 40834 & 41918 & 44561 & 26229 & 35679 & 149244 & 199678 \\
\hline \multirow{2}{*}{ Romania } & 1990 & 1992 & 1996 & 2000 & 2004 & 2008 & 2012 & \\
\hline & NA & 43765 & 73302 & 33151 & 40816 & 23807 & 60634 & \\
\hline \multirow{2}{*}{ Slovakia } & 1990 & 1992 & 1994 & 1998 & 2002 & 2006 & 2010 & 2012 \\
\hline & 0 & 0 & 0 & 0 & 0 & 3427 & 5861 & 7051 \\
\hline \multirow{2}{*}{ Slovenia } & 1992 & 1996 & 2000 & 2004 & 2008 & 2011 & & \\
\hline & NA & JA & JA & JA & 11262 & 10778 & & \\
\hline
\end{tabular}

Note: The value of zero corresponds to those elections in which external voting was not in effect. NA stands for 'data not available'. In Slovenia, there are no official records of external votes for the pre-2008 elections although external voting has been in effect since 1992. All the data were obtained from the CEE-10 national authorities. 
Figure 1 Emigrants' Share in the Total Population of the Sending Countries 1990-2012

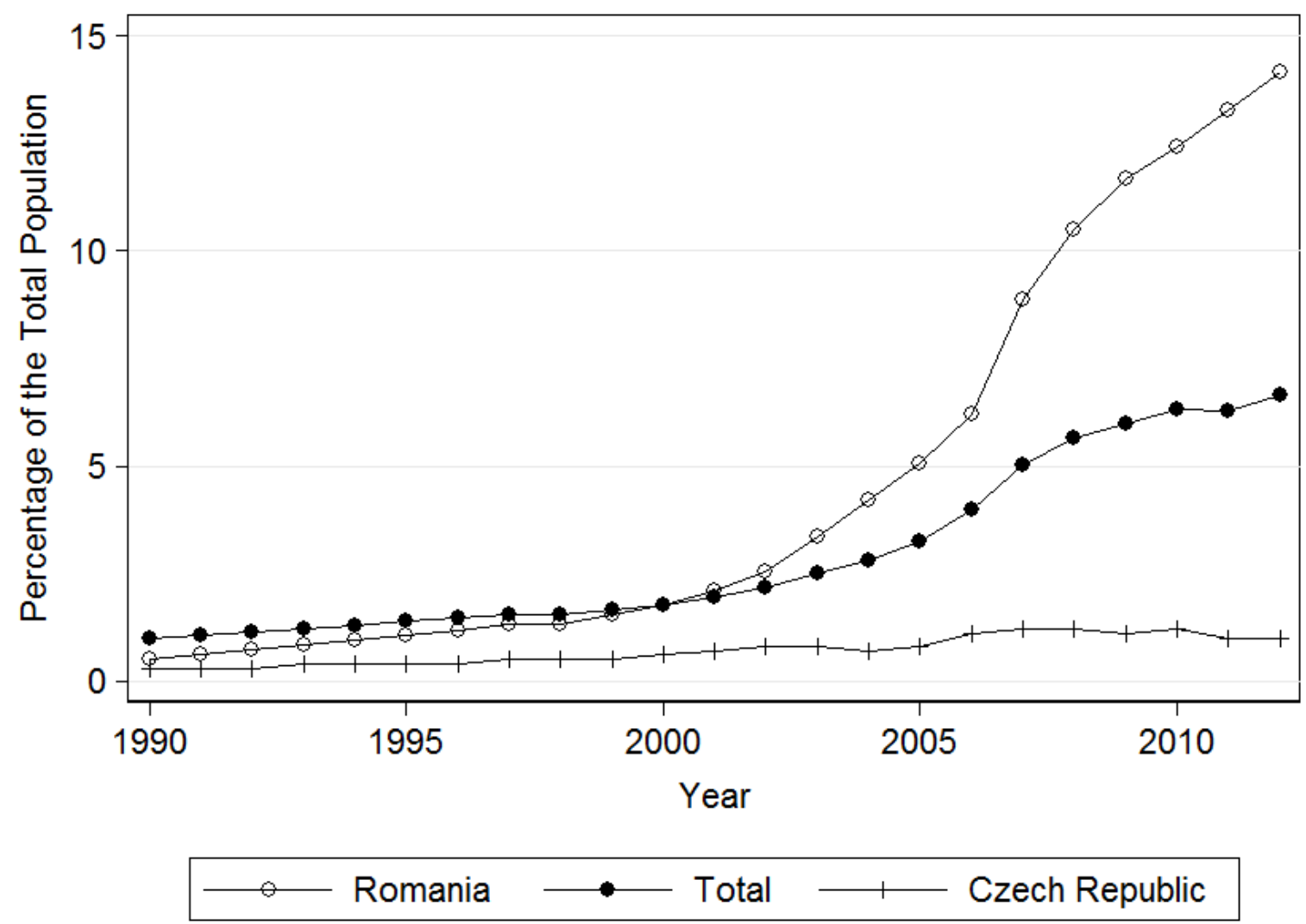

Note: Romania and the Czech Republic display respectively the highest and lowest share of emigrants among the CEE-10. Source: EA Table 12. 
Figure 2 Average Nationwide and External Voting Rates

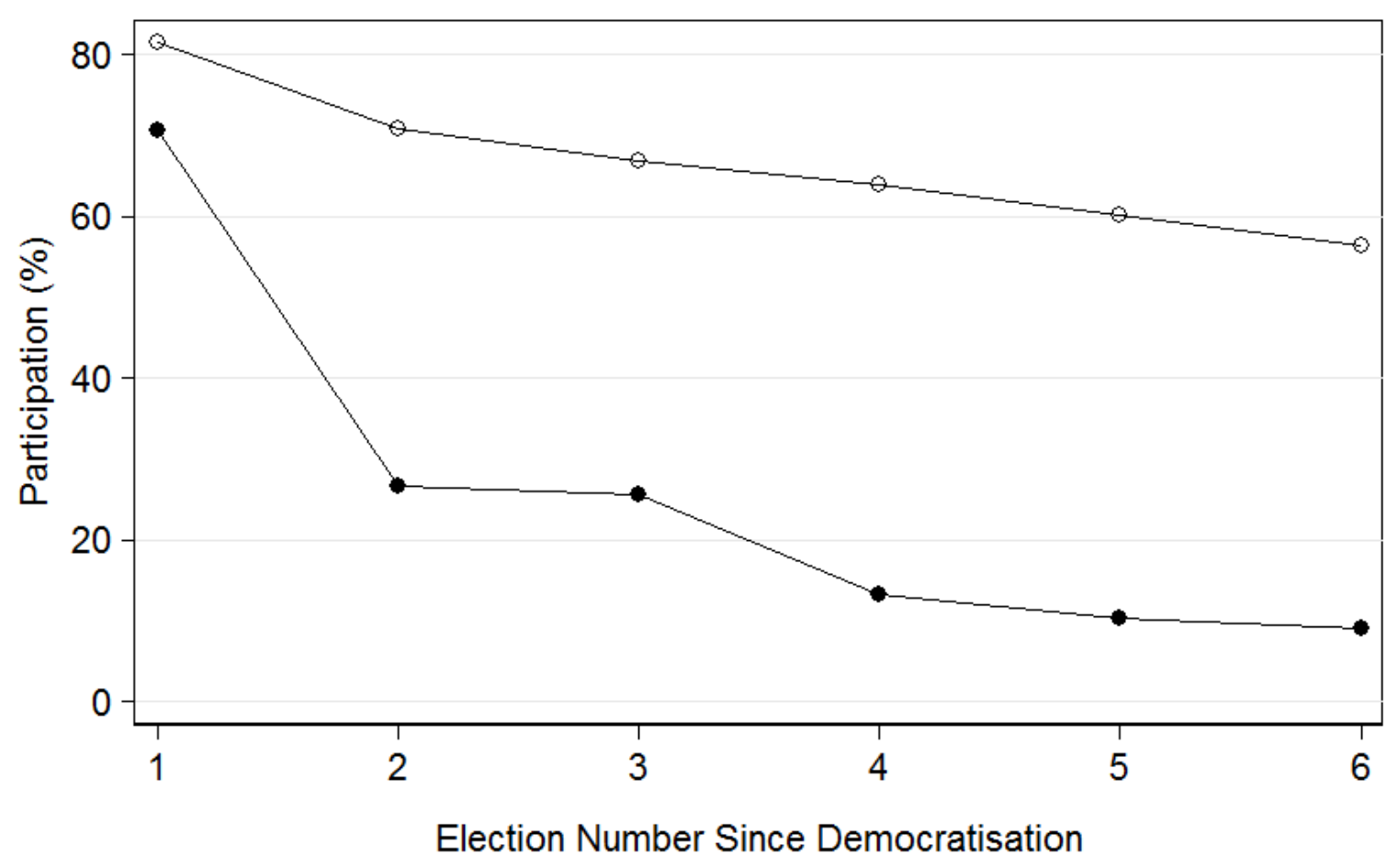

$\longrightarrow$ Nationwide Voter Turnout $\longrightarrow$ External Voter Turnout

Note: Disaggregated rates are presented in Figure 3. 
Figure 3 Nationwide and External Voting Rates by Country

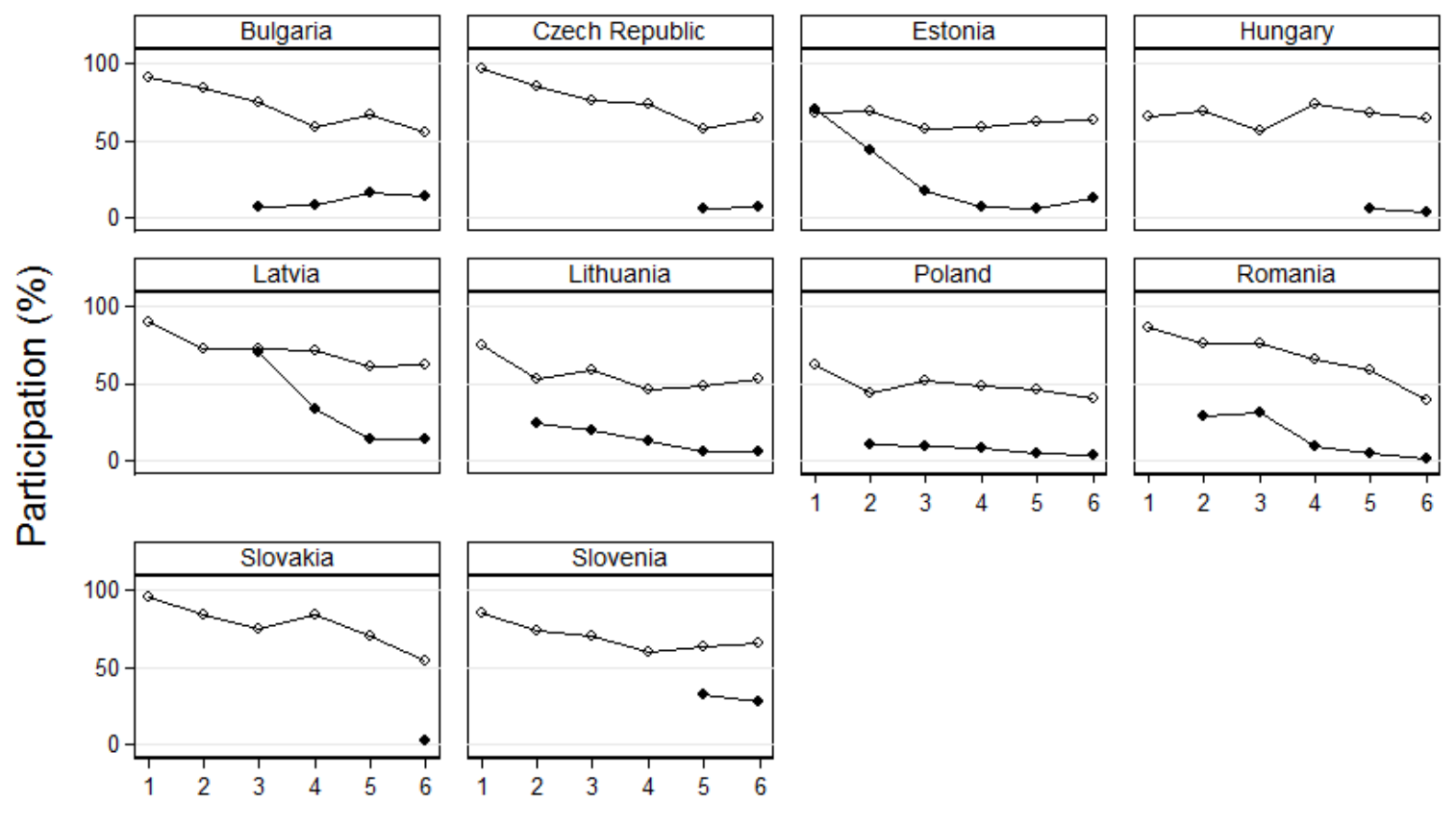

Election Number Since Democratisation

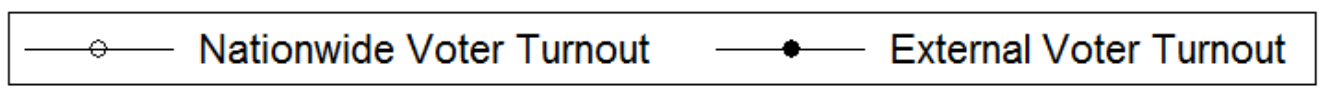

Note: The missing observations for external voting turnout correspond to years in which external voting was not practiced or to missing data. See EA Table 10 for details. 